\title{
Collection and Discovery: Indigenous Guides and Alfred Russel Wallace in Southeast Asia, 1854-1862
}

Carey McCormack

To cite this article: McCormack, Carey. "Collection and Discovery: Indigenous Guides and Alfred Russel Wallace in Southeast Asia, 1854-1862." Journal of Indian Ocean World Studies, 1 (2017), pp. 110-127.

More information about the Journal of Indian Ocean World Studies can be found at: jiows.mcgill.ca

(C) Carey McCormack This is an Open Access article distributed under the terms of the Creative Commons License CC BY NC SA, which permits users to share, use, and remix the material provide they give proper attribution, the use is non-commercial, and any remixes/transformations of the work are shared under the same license as the original. 


\section{Collection ANd Discovery: Indigenous Guides and Alfred Russel Wallace in Southeast Asia, 1854-1862}

Carey McCormack

Washington State University, Washington

\section{Abstract}

This study uses the correspondence and published narratives of Alfred Russel Wallace's travels in Southeast Asia to reveal the significant contributions of indigenous Southeast Asians in the development and advancement of scientific knowledge in the region. This analysis problematizes the Eurocentric narrative of discovery as a primarily white, male endeavour, and instead argues that discovery could only occur with the assistance of a vast network of knowledge and exchange. Chinese immigrants, female travel writers, indigenous tribes, and European assistants made up a significant part of this network, but scientists such as Wallace often exclude these people from their public narratives of "discovery."

Between the seventeenth and nineteenth century, a significant shift in European attitudes towards the collection and diffusion of plants found in the extra-European world occurred. As Londa Schiebinger points out, bio-prospecting (the collection and diffusion of commodity plants such as drugs or food) became a highly profitable business during early European expansion in the Americas and Asia. European governments protected their colonial borders fiercely in order to prevent rival powers' access to commodity plants that they had found, although such monopolies were inevitably threatened by smugglers. ${ }^{1}$ However, the nineteenth century represented a shift away from such mercantilist thought as it marked a growth in inter-European and inter-imperial collaboration that permitted naturalists to collect flora and fauna wherever they wished and gain access to foreign botanical gardens and natural museums. Consequently, "European" or "Western" (rather than, for example, French, British or German) science and notably botany - a field that

1. Londa Schiebinger, Plants and Empire: Colonial Bioprospecting in the Atlantic World (Cambridge, MA: Harvard University Press, 2004), 38. 
was becoming increasingly professionalized - developed.

Most British botanists active in Southeast Asia aimed to categorize and define nature according to new scientific theories, such as evolution, and to search for new commodities, such as rubber, that would promote British economic expansion. ${ }^{2}$ Many historians therefore connect the diffusion of scientific knowledge with imperial hegemony. ${ }^{3}$ Imperialism created hierarchies of power that were also reflected in interactions between European naturalists and local peoples. Indeed, conventional Eurocentric narratives of nineteenth-century botanic and other scientific explorations portray such expeditions as primarily white, male endeavors. Again, while most historians of colonial botany acknowledge that botanists and naturalists used local guides to collect specimens and indigenous information, they rarely accord these assistants more than cursory attention. Some historians of science and empire - a growing field of historical inquiry - focus on the development and hardening of colonial categories such as gender, race and class; others discuss the worldwide search for drugs and natural commodities that spurred European expansion in the Americas, Africa and Asia. ${ }^{4}$ However, several historians neglect the diversity of people, notably those indigenous to the region concerned, engaged in the network of exchange of ideas and knowledge as well as in the collection of plant and animal specimens.

This study focuses on the work of Alfred Russel Wallace (1823-1913), one of the most famous naturalist explorers and the subject of a considerable literature. For eight years, Wallace visited various Southeast Asian islands collecting specimens of local flora and fauna. His work was different from most other British naturalists in that he was self-taught and independent, funding his travels not with government or academic grants, but by selling his collections through a broker in London. ${ }^{5}$ Because of his lack of governmental affiliation, Wallace could more easily obtain the necessary authorization to travel and collect extensively in regions beyond British control. Typically, Wallace, and those writing about him, excluded or marginalized Asians and other local assistants from their published accounts of his voyages in Southeast Asia. This article reveals, through a re-examination of both Wallace's published travel journals and personal correspondence, not only the significant role played by Chinese immigrants, female travel writers, members of indigenous ethnic groups, and European assistants in furthering his work in Southeast Asia, but also the contribution of indigenous Southeast Asians in the development and

2. Richard Drayton, Nature's Government: Science, Imperial Britain, and the 'Improvement' of the World (New Haven: Yale University Press, 2000). Drayton, Nature's Government, 194.

3. Drayton, Nature's Government, 194.

4. Londa Schiebinger and Claudia Swan, eds., Colonial Botany: Science, Commerce, and Politics in the Early Modern World (Philadelphia: University of Pennsylvania Press, 2005).

5. John van Whye, Dispelling the Darkness: Voyage in the Malay Archipelago and the Discovery of Evolution by Wallace and Darwin (London: World Scientific Publishing, 2013), 37. 
advancement of scientific knowledge of the region. ${ }^{6}$

The first section of this article comprises a brief survey of the relevant historiography, the second explains the methodology used, and the third analyses Wallace's journals and personal communications. The article highlights three themes. The first is the diversity of the networks Wallace engaged in, focusing specifically on two issues: his interactions with Chinese immigrant labourers, indigenous groups, European female travel writers, translators, European missionaries, government officials (mainly French and Dutch connections), and his exchange of knowledge with other European collectors in the region. The second focuses on Wallace's employment of a British assistant, and in what ways his use of British assistants differed from that of Chinese immigrants and indigenous groups. It deconstructs the various roles in which indigenous people functioned in connection with Wallace. The third and final theme develops the argument that the collection and diffusion of scientific knowledge depended on a diverse network of exchanges between various European and often unnamed indigenous agents.

\section{Historiography OF British IMPERIAL BotaNy}

Since the 1970s, science (particularly botany) and empire have been popular subjects of inquiry in the discipline of history, notably among British imperial historians. Several scholars initially argued that science was motivated purely by curiosity, and was thus neutral. ${ }^{7}$ They generally focused on major figures in scientific discovery, such as Joseph Banks (1743-1820), William Hooker (1785-1865), Charles Darwin (1809-1882), and Joseph Dalton Hooker (1817-1911), whom they represented as "heroic" pioneers in the categorization of flora and fauna.$^{8}$ However, these historians failed to problematize the adoption by naturalists of the Linnaean system of classification that gave all flora and

6. This study contributes to previous conclusions made by John van Whye in his extensive research on Alfred Russel Wallace. See John van Whye, "Wallace in Singapore," in Nature Contained: Environmental Histories of Singapore, ed. Timothy P. Barnard (Singapore: NUS Press, 2014), 85-109; and John van Whye, Dispelling the Darkness: Voyage in the Malay Archipelago and the Discovery of Evolution by Wallace and Darwin (London: World Scientific Publishing, 2013). For biographical information of the assistants discussed in this study, see Kees Rookmaaker and John van Whye, "In Alfred Russel Wallace's Shadow: His Forgotten Assistant, Charles Allen (1839-1892)," Journal of the Malaysian Branch of the Royal Asiatic Society, 85, no.part 2 (2012): 17-54; and John van Whye and Gerrell M. Drawhorn, “' I am Ali Wallace': The Malay Assistant of Alfred Russel Wallace," Journal of the Malaysian Branch of the Royal Asiatic Society, 88, no.part 1 (2015): 3-31

7. Nigel Hepper, ed., Plant Hunting for Kew (London: HMSO, 1989); Kenneth Lemmon, The Golden Age of Plant Hunters (London: Phoenix House Publications, 1968).

8. Sir John Barrows, The Eventful History of the Mutiny and Piratical Seizure of H.M.S. Bounty: Its Causes and Consequences (London: John Murray, Albemarle-Street, 1831); Leonard Huxley, Life and Letters of Sir Joseph Dalton Hooker, vol. 1 (London: John Murray, 1918), viii. 
fauna Latin names and categorized them according to genus, species and sub-species. ${ }^{9}$ Carl Linnaeus (1707-1778) excluded non-Western indigenous terms for plants and animals because he deemed them to be too difficult for Europeans to pronounce or remember. ${ }^{10}$ The Linnaean system is thus an example of Western scientific appropriation and codification of non-European knowledge into "European" science.

However, in the debate that followed the 1978 publication ofEdward Said's Orientalism, scholars began to problematize the supposedly unbiased development of "Western" science. ${ }^{11}$ Several revisionist historians, including Lucile Brockway, Richard Drayton, and Londa Schiebinger, linked the professionalization of botany with the expansion of empire. ${ }^{12}$ Brockway focused primarily on botanical gardens as centres for experimentation in, and the dispersion of, a wide variety of flora and plant products ranging from medicinal plants like cinchona to cash crops such as rubber, while Drayton argued that English imperialists believed that, if not used "profitably," land in extra-European regions should be forfeited to those who could maximize its commercial potential. Drayton further claimed that leading botanists such as Banks and Joseph Hooker dispatched collectors to both gain scientific knowledge about and promote the economic profitability of colonies. In her turn, Schiebinger demonstrated that while European botanists successfully transplanted the Caribbean peacock flower (Caesalpinia pulcherrima) to Europe, where it became a favoured ornamental in many gardens, they failed to transfer to Europe the knowledge that slave women in the West Indies used it as an abortive. This, she argued, represented "agnotology," the purposeful suppression in Western science of non-European knowledge. More recent revisionist work focuses on the role of science as a measurement of civilization in which, due to the lack of professionalized science in Africa and Southeast Asia, Africans and Southeast Asians were categorized as "uncivilized."13 Again, some historians, noting

9. Antonio Lafuente and Nuria Valverde, "Linnaean Botany and Spanish Imperial Biopolitics," in Colonial Botany, 137.

10. Marie-Noelle Bourguet, Christian Licoppe, and H. Otto Sibum, eds., Instruments, Travel and Science: Itineraries of Precision from the Seventeenth to the Twentieth Century (New York: Routledge, 2002), 203.

11. Edward Said, Orientalism, (New York: Vintage Books, 1979).

12. Schiebinger, Plants and Empire; Richard Drayton, Nature's Government; Lucile H. Brockway, Science and Colonial Expansion: The Role of the Royal Botanic Gardens (New York: Academic Press, Inc., 1979). See also Londa Schiebinger and Claudia Swan, eds., Colonial Botany: Science, Commerce, and Politics in the Early Modern World (Philadelphia: University of Pennsylvania Press, 2005) and David Philip Miller and Peter Hanns Reill, eds., Visions of Empire: Voyages, Botany, and Representations of Nature (Cambridge: Cambridge University Press, 1996).

13. Brett M. Bennett and Joseph M. Hodge, eds., Science and Empire: Knowledge and Networks of Science Across the British Empire, 1800-1900 (New York: Palgrave Macmillan, 2011); Michael Adas, Machines as the Measure of Men: Science, Technology, and Ideologies of Western Dominance (Ithica: Cornell University Press, 1989). 
the omission of reference in conventional histories to the role of gender, have focused on the contribution of women to the nineteenth-century naturalist network of knowledge and specimen exchange. ${ }^{14}$ Women often traveled with their husbands who worked as colonial administrators, scientists, or soldiers, and they frequently published journals of their voyages. Others traveled independently, funding their voyages by publishing travel narratives that often focused on indigenous flora, specimens of which they reproduced in drawings and paintings. Their work, often neglected, needs to be included in any historical analysis of science and empire. ${ }^{15}$

\section{METHODOLOGY}

During Wallace's expeditions to isolated regions of mainland and island Southeast Asia, he relied entirely on local guides and assistants as trail guides, servants, interpreters, and hunters. He thus depended on traditional systems of exchange. Networks theory provides a useful methodology to apply here as it helps to reveal the complex nexus of exchange within which Wallace worked, and it moves away from focusing on centre/periphery dynamics between London and Singapore. Tony Ballantyne's Orientalism and Race: Aryanism in the British Empire (2002), for example, utilized networks theory to focus on systems of exchange used to disseminate information across the British Empire. ${ }^{16}$ As opposed to the centre/periphery dichotomy of Immanuel Wallerstein's World-Systems Analysis, ${ }^{17}$ he suggests that there were many nodes of imperial power. Networks theory allows for the historical inclusion of people integral to the collection of natural specimens

14. Mary Poovey, Uneven Developments: The Ideological Work of Gender in Mid-Victorian England (Chicago: The University of Chicago Press, 1988); Cynthia Eagle Russett, Sexual Science: The Victorian Construction of Womanhood (Cambridge: Harvard University Press, 1989); Londa Schiebinger, Nature's Body: Gender in the Making of Modern Science (Boston: Beacon Press, 1993); Suzanne Le-May Sheffield, Women and Science: Social Impact and Interaction (Santa Barbara: ABC-CLIO, Inc., 2004); Ann B. Shteir, Cultivating Women, Cultivating Science (Baltimore: The Johns Hopkins University Press, 1996).

15. Lila Marz Harper, Solitary Travelers: Nineteenth-Century Women's Travel Narratives and the Scientific Vocation (London: Associated University Presses, 2001); Susan Morgan, Place Matters: Gendered Geography in Victorian Women's Travel Books About Southeast Asia (New Brunswick: Rutgers University Press, 1996).

16. Tony Ballantyne, Orientalism and Race: Aryanism and the British Empire (New York: Palgrave Macmillan, 2002). For a historiography on the use of networks theory in connection to the British Empire, sSee also Natasha Glaisyer, "Networking: Trade and Exchange in the Eighteenth-Century British Empire," The Historical Journal 47, no. 2 (2004): 451-476 for a historiography on the use of networks theory in connection to the British Empire.

17. Immanuel Maurice Wallerstein, World-systems analysis: theory and methodology (Ann Arbor, MI: U.M.I. Books on Demand, 1993). 
but who were often excluded from public narratives of their discovery.

I specifically use the methodology proposed in Tensions of Empire (1997) by Ann Laura Stoler and Frederick Cooper who suggest that colonies influenced the imperial cores and shaped relations across the globe based on categorizations and ideological constructions of gender, race, and class. ${ }^{18}$ In order to produce a more sophisticated core/ periphery analysis, Stoler and Cooper argue that historians should move away from postcolonial narratives that look for subaltern voices within European archival materials and instead read sources "with the grain," i.e. analyze only what authors state explicitly. My intention in using Wallace's letters and published accounts is to also read "with the grain" and focus on Wallace's local assistants. Comparing his letters with his published accounts reveals Wallace's private opinions as opposed to his often significantly different public representations of his activities and the people he encountered. ${ }^{19}$

\section{Alfred Russel Wallace}

Alfred Russel Wallace was born on 8 January 1823 into a declining middle-class English family residing in Wales. As Wallace's father was a gentleman of leisure, and as the family grew larger and investments failed, the Wallace family slipped into decline. However, Wallace attended a boarding school where he received a classical education, occasionally tutoring other students to pay for his education. At the age of fourteen he left school and joined his older brother as an apprentice surveyor. ${ }^{20}$ During the six years that he worked as a surveyor, he first developed an interest in natural history, initially in botany, and subsequently in insect collecting. ${ }^{21}$ In 1845 , after reading works on natural laws and species diversity, he became an evolutionist. Three years later, he traveled to the Amazon rainforest with his friend Henry Walter Bates, whom he had met in 1844 while teaching in Leicester. Bates and Wallace intended to collect natural history specimens with the aspiration of joining the ranks of prestigious naturalists, such as Alexander von Humbolt. ${ }^{22}$ Unfortunately for Wallace, his collection was lost when the ship carrying it

18. Ann Laura Stoler and Frederick Cooper, eds., Tensions of Empire: Colonial Cultures in a Bourgeois World (Los Angeles: University of California Press, 1997), 1-56.

19. For further studies on decentering European narratives and on cross- cultural exchange, see: Kenneth Pomeranz, The Great Divergence: China, Europe and the Making of the Modern World Economy (Princeton: Princeton University Press, 2000); Victor Lieberman, ed., Beyond Binary Histories: ReImagining Eurasia to c. 1830 (Ann Arbor: The University of Michigan Press, 1999); Janet L. AbuLughod, Before European Hegemony: The World System A.D. 1250-1350); and Jerry Bentley, Old World Encounters: Cross-Cultural Contacts and Exchanges in Pre-Modern Times (Oxford: Oxford University Press, 1993).

20. van Whye, Dispelling the Darkness, 10-13.

21. van Whye, Dispelling the Darkness, 21-22.

22. van Whye, Dispelling the Darkness, 26 and 29. 
sank at sea in 1852. Despite the loss of all his specimens and notes, Wallace published two books and gave several talks to scientific communities in London based on his voyage to the Amazon. This networking provided him with later contacts in Southeast Asia but also contacts in London, and allowed him to publish scientific papers. ${ }^{23}$ In 1854, Wallace sailed to Southeast Asia with his assistant, Charles Allen, in order to collect specimens that would further establish his position within the community of gentlemen naturalists. He spent eight years in the Malay Archipelago during which time he collected 110,000 insects, 7,500 shells, 8,050 birds, and 410 mammals and reptiles. This collection formed the basis for a number of papers that Wallace published through both his London broker, Samuel Stevens, and naturalist friends, including Charles Darwin and Bates. ${ }^{24}$ Indeed, his version of the Origin of Species and Evolution was published in tandem with Charles Darwin's ground-breaking theory, even though Darwin wrote (but did not publish) his theory in 1844, and Wallace did not include theories on species diversity until the mid-1850s. ${ }^{25}$ The leading historian on Wallace and Darwin, John van Whye, argues that Darwin did not develop any theories until his return to England from the Galapagos Islands, while Wallace developed his theories while working in the "field" in Southeast Asia. Darwin developed his theory after several years of analyzing his findings from the Galapagos Islands which were limited in biodiversity. The jungles of island Southeast Asia provided a vast array of biodiversity for Wallace who used this research to develop his theories on evolution as he categorized his collections. ${ }^{26}$ This explains why these two men published at the same time even though their field research occurred in different decades. This appears not to have troubled Wallace, whose correspondence with Darwin suggests a deep friendship with mutual sharing ideas and collected specimens. ${ }^{27}$

Nineteenth-century scientists respected Wallace's work and held him in high esteem. Frederick Orpen Bower, chair of the Department of Botany at the University of Glasgow in 1885, considered Wallace's Malay Archipelago to be one of the three most important books of what he described as the "Golden Age" of scientific travel writing, alongside Joseph Dalton Hooker's Himalayan Journals and Darwin's writings on the voyage of the Beagle. ${ }^{28}$ Wallace's book complemented Darwin's on the theory of evolution and origins of

23. van Whye, Dispelling the Darkness, 36-37.

24. van Whye, Dispelling the Darkness, 34-35. Samuel Stevens owned an agency which sold natural history specimens to collectors and institutions for a commission of $20 \%$. Bates and Wallace hired Stevens for the Amazon trip and Wallace retained his services again for the Southeast Asia trip.

25. van Whye, Dispelling the Darkness, 32.

26. van Whye, Dispelling the Darkness, 6.

27. George Beccaloni, “Mini Biography,” The Alfred Russel Wallace Correspondence Project, accessed April 17, 2015, http://wallaceletters.info/content/mini-biography.

28. Alfred Russel Wallace, The Malay Archipelago: The Land of the Orang-utan and the Bird of Paradise. A Narrative of Travel with Sketches of Man and Nature, vol. 1 and 22 vols. (London: Macmillan, 1869, Kindle edition 2013). David Arnold, Tropics and the Traveling Gaze: India, Landscape, and Science, 
species, which is unsurprising given that he and Darwin corresponded with one another while they were writing their respective texts and both scientists had consulted the same background books. ${ }^{29}$ Nineteenth-century scientists read Wallace's Malay Archipelago for its scientific content, and the general public for its exotic descriptions of Southeast Asia. Wallace's "expert" opinion ensured the wide circulation of the work which, legitimized by his discoveries, also documented his interactions with local people. Its importance, and that of his other published works, must be evaluated in the context of his status as an independent and self-funded collector, who generally worked outside British imperial territories, and depended heavily on help from local people, notably indigenous guides, government officials, fellow travelers and naturalists, and European and Malay assistants. In his writings, Wallace represented himself as a "solitary traveler," a familiar and popular trope in travel literature of the time that enhanced the adventurous aspect of travelers' exotic voyages. The Malay Archipelago is organized into articles, each of which deals with different islands. This gives it a coherent travel trajectory that his personal letters lack. Each article reads as a first person, individual account of Wallace experiencing new places and peoples. However, Wallace in fact rarely traveled alone. He often hired several local people as guides and porters, and his assistants, notably, helped with hunting and preserving collections. While the image of the solitary traveler provided a romantic literary device, it was no more than a trope.

While he had much more freedom and time to travel around the islands of Southeast Asia than his contemporaries, who were financed by various organizations in Britain, Wallace was nonetheless hindered by his lack of affiliation. ${ }^{30}$ Unlike Joseph Dalton Hooker, whose expenses were met by the Royal Botanic Gardens at Kew, Wallace sometimes found himself unable to move further due to a lack of funds. ${ }^{31}$ This is important to note, as his book neglects to discuss either monetary obstacles, or the fact that in such situations he became heavily dependent on local assistance. In his personal correspondence, however, Wallace explicitly states that other naturalists had "outdone" him because their activities

1800-1856 (Seattle: The University of Washington Press, 2006), 223. W. H. Lang, 'Bower, Frederick Orpen (1855-1948)', rev. Thomas Junker, Oxford Dictionary of National Biography, Oxford University Press, 2004 [http://www.oxforddnb.com/view/article/31999, accessed 5 April 2017]

29. van Whye, Dispelling the Darkness, 32. Van Whye describes many different theories circulating during the mid-nineteenth century revealing there was not one theory of evolution before Darwin's and Wallace's publications but there were many ideas leading up to origins of species.

30. The distinction being made here is between naturalists funded by the network of botanic gardens connected to Kew in London and those funded by scientific societies. While organizations such as the Royal Society provided some funding, it was often limited compared to government funding through the botanic gardens or through East India Company service.

31.The Natural History Museum (hereafter NHM), Wallace Letters Online, Alfred Russel Wallace to Samuel Stevens, March 10, 1856 and, May 12, 1856. 
were externally financed, while he was self-financing, raising money entirely through selling his collections. ${ }^{32}$

As an independent collector, Wallace's motives are also important to note. Some recent historians have emphasized that the collection of natural science specimens represented European appropriation of indigenous items and resources for the express purpose of expanding empires in Southeast Asia. ${ }^{33}$ However, Wallace was neither connected to a government agency, nor collecting economically viable specimens to be sent to botanical gardens for acclimatization and eventual diffusion to other colonies. While certain institutions attempted to engage Wallace, the "solitary traveler" was careful not to compromise his original goal. For example, William Hooker, Director of the Royal Botanic Gardens at Kew, asked Wallace to collect botanical specimens for Kew. Wallace declined, arguing that collecting plants would take time away from collecting birds and insects: the primary focus of his journey. ${ }^{34}$ Wallace did, in fact, gather some plants, primarily ferns and orchids, but it would appear, from his writings, only to appease the readers interested in botany. ${ }^{35}$ In his works, he also described in detail the flora and landscape of the islands he visited, but out of scientific curiosity and fascination for the natural world rather than for economic gain. This is the primary difference between Wallace and figures such as Joseph Dalton Hooker, whom contemporary nineteenth century scientists considered the premier economic botanist of the time. Wallace's travels, then, form an exception in a historiography that generally represents scientific inquiry in European empires as forms of colonial exploitation.

\section{Diversity OF WALlaCE'S NETWORKS IN THE INDIAN OCEAN WORLD}

A prevailing theme in Wallace's personal correspondence and published work is the help he received in the field from Europeans and Southeast Asians. Wallace noted the importance to him of French missionaries early in his correspondence with his mother and sister. Wallace and his assistant, Charles Allen, lived with French Jesuit missionaries in Singapore as the lodging was free and the missionaries spoke Chinese and Malay. ${ }^{36}$ Wallace spoke fluent French, which facilitated his relationship with the Jesuits who, on several occasions, in Singapore, Borneo, and Sarawak, acted as translators for him. Although raised a Protestant, Wallace also praised French missionary endeavours. For

32. NHM, Wallace Letters Online, Alfred Russel Wallace to Fanny Sims, October 10, 1861.1.

33. Schiebinger and Swan, "Introduction," in Colonial Botany, 15; Gascoigne, Science in the Service of Empire.

34. NHM, Wallace Letters Online, Alfred Russel Wallace to William Jackson Hooker, October 10, 1854 and Alfred Russel Wallace to George Silk, October, 15, 1854.

35. Wallace, Malay Archipelago, Chap. 5.

36. NHM, Wallace Letters Online, Alfred Russel Wallace to Mary Ann Wallace, May $28^{\text {th }}, 1854$. 
example, in a published article on the Celebes, he commented favourably on missionary work there, from introducing the Malay language (which replaced a multitude of local dialects), to assisting the government in "changing the savage into a civilized community," and teaching local converts how to sing. ${ }^{37} \mathrm{He}$ noted further that "there are several [French missionaries] here, each devoted to a particular part of the population Portuguese, Chinese, and wild Malays of the Jungle [sic]." ${ }^{38}$ By contrast, he remarked on the lack of Protestant missionaries in British colonies in the region. ${ }^{39}$ His publications reveal the high level of interaction Catholic missionaries had with local populations in Southeast Asia and China. ${ }^{40}$ Indeed, they acted as intermediaries between European travelers such as Wallace and local indigenous groups. They provided him with information about where he might visit in China and Southeast Asia. ${ }^{41}$ Further, they most likely provided him with plant and animal specimens, as they often kept kitchen gardens, and helped him collect plants of interest that would later be sent to collection stations. ${ }^{42}$ According to Wallace's narrative, missionaries acted as translators and supplied travelers with assistants, other translators and indigenous guides. For example, in Malacca, Wallace stayed with a French missionary who provided him with a young Portuguese man to help with hunting, cooking, cleaning, and preserving specimens (skinning and drying primarily). ${ }^{43}$

Wallace also depended on local colonial government officials for introductions, lodging, and assistants. For instance, while collecting on Lombok, Wallace wrote,

I determined to make an excursion into the interior of the island, accompanied by Mr. Ross, an Englishman born in the Keeling Islands, and now employed by the Dutch Government to settle the affairs of a missionary who had unfortunately become bankrupt here. Mr. Carter kindly lent me a horse, and Mr. Ross took his native groom. ${ }^{44}$

Mr. Carter, the Straits (British) government agent, offered Wallace the government residency for lodging. This was an honour given that Wallace had only met Mr. Carter through a letter of introduction from another resident in Malacca. Wallace's accounts

37. Ibid., article 17.

38. NHM, Wallace Letters Online, Alfred Russel Wallace to Mary Anne Wallace, July 2, 1854.

39. NHM, Wallace Letters Online, Alfred Russel Wallace to Mary Anne Wallace, July 2, 1854.

40. NHM, Wallace Letters Online, Alfred Russel Wallace to Fanny Sims, February 20, 1856.

41. Most references to missionaries in Wallace's writings do not include the specific names of the missionaries he spoke to.

42. Michael Bravo, "Mission Gardens: Natural History and Global Expansion," in Colonial Botany, 49-50.

43. NHM, Wallace Letters Online, Alfred Russel Wallace to Mary Anne Wallace, July 2, 1854.

44. Wallace, The Malay Archipelago, Chap. 21 ter XI. 
reveal similar other stories, indicating that European officials often welcomed and assisted European travelers. In addition to tapping into the French missionary and European official circuits in Asia, Wallace communicated with, and received advice from, other naturalists and botanists in the region, such as Francois Louis Nompar de Caumont Laporte, and those working in other parts of the world, like Henry Walter Bates.

David Arnold argues that, in the mid-nineteenth century, European scientists developed new ideas about the "tropical zone" of the earth. ${ }^{45}$ According to Arnold, naturalists believed that the same plants were found in equatorial regions the world over and that tropical zones, rather than being unique, could sustain plants from other regions. Consequently, botanists and naturalists in tropical zones communicated information to each other across imperial boundaries to ensure that overlapping "discoveries" did not occur. Thus, when in the Malay Archipelago, Wallace provided Bates, who had been working in Brazil, with a long list of specimens that he had collected in Malacca, Singapore, Borneo, and the Celebes, and suggested that Bates created a similar list so that they might compare and catalogue their specimens and prevent the development of duplicate collections. Wallace similarly corresponded with at least two English naturalists in Southeast Asia, and with Francis Castelnau (1810-1880), also known as Francois Louis Nompar de Caumont Laporte. Castelnau, who was French consul in Singapore in 1861, and supervised many botanists active in Siam, Cambodia, Malaya, Sumatra, Borneo, Indonesia, and Burma, proposed collaborating with Wallace to ensure that his cadre of botanists did not collect specimens that Wallace had already gathered and classified. ${ }^{46}$

\section{Gender ANd Collecting}

Despite male dominance of nineteenth-century scientific establishments and knowledge production, a few women undertook research and published in the fields of entomology, geology, and notably botany - in which subject, from 1800 to 1900, they published three times as much as on any other scientific theme. ${ }^{47}$ Early women botanists focused primarily on exploration, observation and classification of the flora of the British Isles, but they increasingly traveled further afield, either as wives of military men or commercial agents, or as travel writers or explorers in their own right. At the same time, women demanded, and were increasingly granted, access to university science programmes.

Several women scientists were active in Southeast Asia in the early to mid-

45. Arnold, Tropics and the Traveling Gaze, 110-111.

46. NHM, Wallace Letters Online, Francois Louis Nompar de Caumont Laporte to Alfred Russel Wallace, August 26, 1861.

47. Mary R.S. Creese, and Thomas M. Creese, Ladies in the Laboratory? American and British Women in Science, 1800-1900: A Survey of Their Contributions to Research. (London: The Scarecrow Press, Inc., 1998), xi. 
nineteenth century. ${ }^{48}$ For example, Wallace referenced Ida Pfieffer, an Austrian naturalist and whose two travel books funded her collecting mission to Singapore, China, Penang, and Ceylon in the 1840s. ${ }^{49}$ Although Pfieffer is absent from Wallace's published work, his correspondence indicates that he carefully studied her collection to ensure that he did not duplicate her work. ${ }^{50}$

The second woman who exemplified female engagement in travel in South and Southeast Asia who collected botanical specimens with the help of indigenous people, and then diffused the botanical information they acquired through publications was Marianne North. ${ }^{51}$ As a wealthy upper-class spinster who traveled around the world, painting and drawing plants, North engaged with indigenous systems of exchange much like her male counterparts. ${ }^{52}$ She had a museum built at Kew Gardens to hold a collection of her plant paintings. She also wrote several books in which she describes her interactions with local people. For example, in Sarawak she stayed with James Brooke, "the White Rajah," whose servants collected specimens for her to paint.$^{53}$ Her last work, published posthumously by her sister, details encounters with indigenous guides who helped her collect plants and accompanied her on journeys which, due to their arduous conditions, would otherwise have been deemed unsuitable for a woman of her status and wealth. For example, while in Borneo, North stated that

the Rajah lent me a cook, a soldier, and a boy, gave me a lot of bread, a coopful [sic] of chickens, and packed us all into a canoe, in which we pulled through small canals and forest nearly all day. ${ }^{54}$

The voyage was made in order for North to reach the Rajah's farm retreat where she could collect plant specimens and paint. North, who spoke of her travels as adventures, traveled

48. Lila Marz Harper, Solitary Travelers: Nineteenth Century Travel Narratives and the Scientific Vocation (Madison: Fairleigh Dickinson University Press, 2001); Susan Morgan, Place Matters: Gendered Geography in Victorian Women's Travel Books about Southeast Asia (New Brunswick: Rutgers University Press, 1996).

49. van Whye, Dispelling the Darkness, 38-39; NHM, Wallace Letters Online, Alfred Russel Wallace to Henry Walter Bates, April 30, 1856.

50. Ida Pfeiffer, A Woman's Journey Round the World From Vienna to Brazil, Chili, Tahiti, China, Hindostan, Persia, and Asia Minor, $2^{\text {nd }}$ ed. (London: 227 Strand, 1852).

51. Collection through illustration or "the gaze" was first theorized by Mary Louise Pratt, Imperial Eyes: Travel Writing and Transculturation (New York: Routledge, 1992) but has recently been argued by Daniela Bleichmar, Visible Empire: Botanical Expeditions and Visual Culture in the Hispanic Enlightenment (Chicago: Univeristy of Chicago Press, 2012).

52. Sheffield, Revealing New Worlds, 76.

53. Marianne North, Recollections of a Happy Life (London: Macmillan and Co., 1892).

54. North, Recollections of a Happy Life, 243. 
beyond local attractions and explored areas of little interest to normal tourists. She, like Wallace, also depended on local guides.

North produced a large number of paintings and published travelogues that encouraged professional botanists to search for specimens she had discovered. Thus, there is a clear link between her production of knowledge and the scientific endeavours of male botanists. However, while it was acceptable, and perhaps even genteel, for women to travel the world and write about their experiences, and their narratives mirrored those of contemporary males such as Wallace, the scientific community of the time never recognized them as legitimate scientists. Indeed, the nineteenth century witnessed the development of theories purportedly demonstrating women's inability to perform scientific inquiry. As several feminist scholars have recently noted, travel writing is still considered by many academics as non-scientific. ${ }^{55}$

\section{European Assistants}

Wallace, like many other leading naturalists before and after him, devalued his European assistants in the field, although they were critical to the success of his ventures. ${ }^{56}$ Wallace's accounts of his European assistants in his books vary from those in his personal correspondence. For example, references to his English assistant, Allen, while largely absent from his published work, are plentiful in his personal correspondence, ${ }^{57}$ According to historians van Whye and Kees Rookmaaker, Allen accompanied Wallace to Southeast Asia at the age of fourteen, and worked with him for several years as an apprentice naturalist. ${ }^{58}$ Wallace expected Allen to perform two main functions. First, he was to act as a servant - cooking, cleaning, chopping and collecting firewood, constructing shelters in the forest bush, and hauling equipment. Second, as Wallace's apprentice, he was expected to learn to be a naturalist within a year. As a naturalist he was to hunt, skin, and dry specimens, and to master the techniques and Latin terms to be able to catalogue plants, animals, and insects, according to the Linnaean tradition.

55. Londa Schiebinger, Nature's Body: Gender in the Making of Modern Science (Boston: Beacon Press, 1993), 9. See also Cynthia Eagle Russett, Sexual Science: The Victorian Construction of Womanhood (Cambridge: Harvard University Press, 1989) and Mary Poovey, Uneven Developments: The Ideological Work of Gender in Mid-Victorian England (Chicago: The University of Chicago Press, 1988).

56. Two articles provide detailed biographies of Wallace's assistants; for Charles Allen, see Rookmaaker and van Whye, "In Alfred Russel Wallace's Shadow," and for Ali, see van Wyhe and Drawhorn, "'I am Ali Wallace."”

57. NHM, Wallace Letters Online, Alfred Russel Wallace to Fanny Sims, February 20, 1856, from Wallace Letters Online.

58. Rookmaaker and van Wyhe, "In Alfred Russel Wallace’s Shadow," 22 \& 36. 
Allen proved himself useful when it came to manual labour but in numerous letters to his sister, Wallace complained of Allen's incompetence as a naturalist, stating that he frequently had to redo Allen's initial work - the inspection, drying and cataloguing of insects. ${ }^{59}$ Wallace informed his mother that Allen was so incompetent that he would like to send him back to England, but was prevented by the expense involved. ${ }^{60}$ Wallace's mother and sister offered to send out a replacement apprentice. ${ }^{61}$ Wallace eventually judged that Allen had learned enough to be trusted as an independent collector, ${ }^{62}$ but in Sarawak, Allen left Wallace to become a missionary agent, working first in Sarawak and later in Borneo and Singapore. ${ }^{63}$

As an independent, self-financing scientist, Wallace could not afford many more assistants. By contrast, naturalists sponsored by governments or institutions could afford to hire an army of helpers. For example, while collecting in northern India, Joseph Dalton Hooker hired almost twenty assistants as both servants and independent collectors specimens. ${ }^{64}$

\section{INDigenOus GUIDES AND LOCAL HELP}

Since Allen only fulfilled part of the duties expected of him and Wallace had insufficient funds to bring out another assistant from England, he turned to indigenous Southeast Asians to act as servants, guides, translators, hunters, and collectors. This in turn revealed his attitude to non-European peoples. Botanists working in extra-European regions increasingly excluded local or indigenous participation in the ownership or production of the scientific knowledge they developed. This reflected a hardening of racial categories, notably within the British Empire.

Wallace was typical in this regard. Despite his earlier sympathy for the plight of the English working class, ${ }^{65}$ Wallace adopted a generally stereotypical European attitude to non-European workers. For instance, Chinese immigrants worked in forestry, mining and agriculture on almost every island Wallace visited in the Malay Archipelago. He often hired these workers to hunt on their days off. His interactions with these men were positive,

59. NHM, Wallace Letters Online, Alfred Russel Wallace to Fanny Sims, June 25, 1855, from Wallace Letters Online.

60. NHM, Wallace Letters Online, Wallace to Mary Ann Wallace, September 30, 1954.

61. NHM, Wallace Letters Online, Wallace to Fanny Sims, June 25, 1855.

62. Rookmaaker and van Whye, "In Alfred Russel Wallace's Shadow," 23.

63. Rookmaaker and van Whye, "In Alfred Russel Wallace's Shadow," 22 \& 36.

64. Joseph Hooker to William Hooker, 9 August, 1848. Hooker Collections, Royal Botanic Gardens Kew, London, http://www.kew.org/science-conservation/collections/joseph-hooker/explore.

65. van Whye, Dispelling the Darkness, 13. In this, Wallace was atypical: see e.g. Linda Nead, Victorian Babylon: People, Streets and Images in Nineteenth-Century London (New Haven: Yale University Press, 2000). 
and he considered that "the greater portion of them are quiet, honest, and decent sort of men." ${ }^{\prime 6}$ Nevertheless, in his writings he focused on factors such as their uncleanliness and dependence on opium. In a letter published in The Literary Gazette and Journal of the Belles Letters, Science, and Art, Wallace stated that

The Chinese are generally considered, and with some truth, to be thieves, liars, and careless of human life, and these Chinese [immigrants in Borneo] are coolies of the very lowest and least educated class. ${ }^{67}$

In the same letter, Wallace condoned the decision by an English manager of a local mine to hire Malays and Dayaks to violently break a strike organized by the mine's Chinese workforce who was protesting against dangerous and poor working conditions. ${ }^{68} \mathrm{He}$ also viewed urban Malays in a particularly unfavourable light, describing them as swindlers who preyed on local indigenous groups by forcing unequal market trades.

By contrast, Wallace adopted a generally favorable attitude to Southeast Asians groups in rural areas, including Malays and Dayaks, who lived in traditional settings. He was particularly concerned that the meeting of East and West would lead to such groups becoming "civilized' rather than commercially exploited, and pushed for British officials to follow the example of the Dutch in establishing benevolent, paternalistic government in their colonies. Should they not, they might face uprisings by indigenous peoples against colonial rule. ${ }^{69}$

\section{SERVANTS}

Indigenous people worked as "coolies" (or servants) who performed domestic labour and often carried equipment. However, European travelers in Southeast Asia not only applied the term "coolie" to a far wider group of people, they also considered them inferior to Indian "coolies" because they purportedly refused to perform certain tasks and would easily tire and abandon work. For example, one botanical collector in Ceylon, Mrs. Anna Maria (née Patton) Walker, complained about her coolies' refusal to carry her in a palanquin for an entire day. In Walker's opinion, all palanquin bearers were animal-like, and she went as

66. Wallace, Letter to unknown recipient in The Literary Gazette, 684.

67. Alfred Russel Wallace, Letter to unknown recipient in The Literary Gazette and Journal of the Belles Letters, Science, and Art, 2023 (1855): 684. http://people.wku.edu/charles.smith/wallace/S022. htm.

68. Wallace, Letter to unknown recipient in The Literary Gazette, 684.

69. This praise of the Dutch administration may have been in direct response to Thomas Stanford Raffles' negative representation of Dutch rule when he occupied Java in 1811. See D. R. SarDesai, Southeast Asia: Past and Present, 5 ${ }^{\text {th }}$ edition (Boulder: Westview Press, 2003), 89. 
far as to label hers "black cattle."70 Her experiences led her to the conclusion that "coolies" in Ceylon were not as subservient as the coolies of India, even though they carried out the same work. Wallace had similar encounters in the less populated regions of Malacca and Borneo where he considered the local men he hired to carry his luggage to be like draught animals. ${ }^{71}$ Nevertheless, Wallace was totally dependent upon local men to carry him and his possessions, and to guide him - which in turn made him vulnerable to any demands they might make.

\section{Guides, Translators, Hunters, and Collectors}

While the skinning and categorization of specimens often - though not always ${ }^{72}$ fell to Allen or Wallace, he employed local people as guides, translators, hunters, and collectors. Colonial government officials, irrespective of which European empire they represented, often facilitated Wallace's introduction to guides, ${ }^{73}$ who he chose according to their availability and knowledge. Some of the guides he hired, Wallace categorized as Dutch or Portuguese, although it is clear from their interactions with villagers that these men were most likely the second or third-generation descendants of European colonists, and would today be considered Southeast Asian. Indigenous guides played critical roles in leading naturalists to regions never previously visited by Europeans. ${ }^{74}$ Nonetheless, Wallace often complained that guides purposefully misled him in order to prevent him from access to some local flora and fauna. For instance, when he failed to see an elephant or a rhinoceros even though he could hear them in the jungle, he thought that his guides were purposefully drawing him away from animals he wanted to shoot, skin and sell in London.

Wallace also sometimes used local people as translators. For example, he hired a Malay boy named Bujon to help him communicate with the Sudong Dayaks of Borneo. ${ }^{75}$ After parting ways with Allen in Sarawak, Wallace also employed indigenous people as servants, and to help him collect, treat, and categorize natural specimens. The first such assistants were two boys, Ali, a Malay, and a Malacca of Portuguese descent. Ali worked as a cook and became Wallace's best hunter and collector and remained with Wallace throughout his time in Southeast Asia. ${ }^{76}$ Of his other indigenous assistants, the most valued was a Chinese servant (his "China boy") who, for example, helped to skin

70. Walker, "Excursion to Adam's Peak," 7.

71. Wallace, The Malay Archipelago, article 7.

72. Wallace, The Malay Archipelago, article 3.

73. Wallace, The Malay Archipelago, article 7.

74. Arnold, Tropics and the Traveling Gaze, 152.

75. Wallace, The Malay Archipelago, article 5.

76. van Whye and Drawhorn, "I am Ali,", 5. 
orangutans in Sarawak, while Wallace hunted with local men. ${ }^{77}$.

Indeed, Wallace largely depended on local people as hunters and collectors. During his expedition to Mount Ophir, he used six Malay not only as porters, who cooked and built shelters for him, but also to clear paths and, alongside Allen, to hunt and collect specimens. ${ }^{78}$ Others he hired specifically to hunt. The clearest example of this was during his expedition to Simunjon, Borneo when Wallace hired local Dayaks to collect orangutans of both sexes at every stage of their growth. ${ }^{79}$ Similarly, in Malacca, Wallace hired local Portuguese and Chinese to shoot birds for his collection, ${ }^{80}$ and in Macassar, planned to hire "a good man to shoot and skin birds and animals" - a collection the sale of which he hoped would fund his return trip to Singapore. ${ }^{81}$ It is notable that Wallace never hired indigenous women whose knowledge, particularly of flora, would have been acute. Indeed, women and children often hid from him when he entered villages. ${ }^{82}$

Many hunters associated with Wallace worked independently. Thus Wallace wrote that one "hunter brought me a specimen of the green gaper (Calyptomena viridis), which is like a cock-of-the-rock, but entirely of the most vivid green, delicately marked on the wings with black bars." ${ }^{\prime 3}$ Wallace never named the hunter and claimed this new species, or possibly subspecies, as his own finding. However, he did, in a published account, indicate that, in Java, a boy brought him a new species of butterfly. ${ }^{84}$ Again, in Sarawak, where Wallace offered one cent to local Dayak and Chinese for every insect brought to him, he obtained a new species of beetle that he named after Sir James Brooks, the selfproclaimed Rajah of Sarawak, who provided introductions and assistants for Wallace in Java and Sarawak. ${ }^{85}$ As van Whye notes, "Wallace's collecting total was so high not because he was a superhuman collector but because he paid a small army of assistants to maximize specimen production," 86

It was customary that specimens collected by assistants be listed as the discovery

77. NHM, Wallace Letters Online, Alfred Russel Wallace to Fanny Sims, June 25, 1855.

78. Wallace, The Malay Archipelago, article 3.

79. NHM, Wallace Letters Online, Alfred Russel Wallace to unknown recipient, May 1855, from Wallace Letters Online.

80. Wallace, The Malay Archipelago, 29; The Malay Archipelago, article 3.

81. NHM, Wallace Letters Online, ARW to Samuel Stevens, May 12, 1862, from Wallace Letters Online.

82. Early Dutch collectors attempted to gain local knowledge of plants and medicine from female sources. It can be assumed Wallace also attempted contact with local women. See Harold J. Cook, "Global Economies and Local Knowledge in the East Indies: Jacobus Bontius Learns the Facts of Nature," in Colonial Botany, 114.

83. Wallace, The Malay Archipelago, article 3.

84. Wallace, The Malay Archipelago, article 7.

85. Wallace, The Malay Archipelago, article 4.

86. van Whye, "Wallace in Singapore," 108. 
of their employers. ${ }^{87}$ Moreover, despite the contribution of local people, Wallace ignored indigenous languages when naming species. Nor did he name any after Allen, his European assistant. Indeed, most nineteenth-century scientists, particularly naturalists and botanists, named new species after European men (including themselves) in order to preserve the fame of patrons for posterity. ${ }^{88}$

\section{Conclusion}

This article seeks to complicate Wallace's literary representation of himself as a solitary traveler, discovering new species and furthering scientific knowledge. In common with other nineteenth-century naturalistsactive in Southeast Asia, Wallaceclaimed that scientific "discovery" could only be the work of professional scientists. However, his interactions with contemporaries, travelers, fellow scientists, and local people, including guides and hunters, suggest that he was rarely a solitary traveler. Rather, Wallace relied on a vast network of people, from colonial administrators to Chinese immigrants and indigenous tribal groups to further his work. Despite extensive help from all of these groups, the natural sciences had by the mid-nineteenth century become exclusive to European men of either the middle or aristocratic classes. A small portion of women from these classes, such as Anna Maria Walker, Ida Pfieffer and Marianne North, attempted to engage in these sciences but were often relegated to publications, such as travelogues, targeted for their own sex. By contrast, indigenous peoples who assisted in, and were essential to, the work of European botanists in the extra-European world were totally excluded from any claim to the production of the scientific knowledge gleaned by Europeans. For example, while many local men and women possessed a profound knowledge of indigenous flora and fauna, and performed many of the same tasks as Wallace, he denied them any claim to the production of knowledge because of their inability to classify their knowledge according to the Linnaean tradition.

In sum, Wallace's eight-year sojourn in the Malay Archipelago represents both the colonial appropriation of indigenous knowledge and an act of exploration based on scientific curiosity and the active exchange of information within a diverse network in British colonies. Many historians argue that Western science aided the expansion of empire and thus the exploitation of colonial resources. However, while Wallace's discoveries contributed to the collection in London's Natural History Museum he did little to promote economic botany or new drugs. Wallace's work in Southeast Asia relied on a vast network of encounters, exchanges and assistance with indigenous peoples who he excluded from claims to the act of discovery and production of scientific knowledge.

87. van Whye and Drawhorn, "'I am Ali,", 15.

88. Schiebinger, Plants and Empire, 198. 